\title{
PRINCIPLE OF CLEAN HANDS AND PROTECTION OF HUMAN RIGHTS IN INTERNATIONAL INVESTMENT ARBITRATION
}

\author{
Marcin Kałduński*
}

\section{Introduction}

The principle of clean hands can be defined as a principle that protects a party from the illegal or improper conduct of another party when such conduct has provoked illegal or improper behaviour of the first party. Accordingly, the second party may not, upon committing an intentionally wrongful act or acting improperly, claim legal protection against the first party or benefit from its previous conduct. Thus, an action may not be brought before court by someone who has behaved improperly with respect to the subject matter of the claim and the opposite party. ${ }^{1}$ With this in mind, it is submitted that the principle consists of the following elements:

- illegal or improper conduct of the first party;

- subsequent conduct of the second party which may consist of (a) a non-performance of an international obligation, or (b) an internationally wrongful act;

* Assistant professor, Department of International Law, Faculty of Law and Administration, Nicolaus Copernicus University.

1 See Sixth report on diplomatic protection by John Dugard, Special Rapporteur, 11.8.2004, UN Doc. A/CN.4/546, at para. 2. 
- casual relationship between the conduct of the first party and the subsequent conduct of the second party;

- the conduct of the second party must be proportional with respect to the conduct of the first party. ${ }^{2}$

The principle of clean hands is, to a certain extent, expressed by Latin maxims, including ex turpi causa non oritur actio (ex dolo malo non oritur actio, ex delicto non oritur actio) and nullus commodum capere potest de sua iniuria propria (nemo potest commodum capere de sua iniuria propria). It has been emphasised that this principle reflects equitable principles derived from Anglo-American law. Sir Gerald Fitzmaurice held that "[h]e who comes to equity for relief must come with clean hands." Thus a State which is guilty of illegal conduct may be deprived of the necessary locus standi in judicio for complaining of corresponding illegalities on the part of other States, especially if these were consequential on or were embarked upon in order to counter its own illegality - in short were provoked by it." ${ }^{3}$ P. Reuter remarked that the notion of clean hands has quite a rich substance but is slightly heterogeneous and disorganised (hétérogène et désordonnée). ${ }^{4}$ It is, perhaps, the reason why neither the PCIJ nor the ICJ have ever applied the principle. The vague, inconsistent, and dubious legal nature of the principle of clean hands was confirmed by the Arbitral Tribunal acting under the UN Convention on the Law of the Sea. It reviewed the case-law only to find that "the use of the clean hands doctrine has been sparse, and its application in the instances in which it has been invoked has been inconsistent." ${ }^{5}$ The Tribunal was also careful to distance itself from recognising the principle as part of positive international law by saying that

2 This element was emphasised by: E. Borchard, Diplomatic Protection of Citizens Abroad, The Banks Law Publishing Co., New York 1915, pp. 717, 735; J.J.A. Salmon, Des "mains propres » comme condition de recevabilité des reclamations internationals, 'Annuaire Français de Droit International' 1964, vol. 10, at pp. 225, 246.

3 G. Fitzmaurice, The General Principles of International Law, RCADI 1957-II, vol. 92, at p. 119.

4 P. Reuter, Counsel for the Government of Spain, Annexes to the Minutes of the Public hearings held at the Peace Palace, The Hague, from 16 April to 19 May 1964, the President Sir Percy Spender, presiding (concluded), Barcelona Traction, Light and Power Company, Limited (Belgium v. Spain) (New Application: 1962), 27.4.1964, I.C.J. Pleading, Oral Arguments, Documents 1970, vol. III, at pp. 680-681.

5 Guyana v. Suriname, PCA, Award of 17.9.2007, at para. 418. 
[t]he doctrine of clean hands, as far as it has been adopted by international courts and tribunals, does not apply in the present case" and "Guyana's conduct does not satisfy the requirements for the application of the doctrine of clean hands, to the extent that such a doctrine may exist in international law. ${ }^{6}$

Nonetheless, the Arbitral Tribunal made an attempt to establish necessary elements (criteria) of the principle of clean hands in order to demonstrate that none of them had been present. ${ }^{7}$

The principle of clean hands has been discussed by judges in their opinions. For example, Judge Anzilotti, in his dissenting opinion in the Legal Status of Eastern Greenland case, stated that "an unlawful act cannot serve as the basis of an action at law." " Judge Hudson, in his individual opinion in Diversion of Water from the Meuse, noted the maxim whereby "a court of equity refuses relief to a plaintiff whose conduct in regard to the subject-matter of the litigation has been improper." ${ }^{.9}$ In Military and Paramilitary Activities in and against Nicaragua, Judge Schwebel, in a dissenting opinion, was of the view that the Court should have rejected Nicaragua's claims because it had not come to the Court with clean hands:

6 Ibid., paras 418, 421.

7 Ibid., para. 419-421. They are as follows: (i) the breach has a continuing character, (ii) the protection sought must be against continuance of that violation in the future, rather than reparations for past violations, and (iii) there must be an identical or reciprocal obligation which the demandant is not performing. It seems that the Tribunal reviewed the conduct of the parties in light of the principle of clean hands to be confident that it is not applicable in the case. The careful analysis shows that the Tribunal's concept of clean hands is related more to countermeasures than to the principle of clean hands, as defined above, in the main text.

8 Dissenting Opinion by M. Anzilotti, Legal Status of Eastern Greenland, Judgment of 5.4.1933, PCIJ Publ., Series A/B, No. 53, at p. 95.

9 Individual Opinion by Mr Hudson, Diversion of Water from the Meuse, Judgment of 28.6.1937, PCIJ Publ., Series A/B, No. 70, at p. 77. See also: Dissenting opinion of Judge Morozov, United States Diplomatic and Consular Staff in Tehran (United States of America v. Iran), Judgment of 24.5.1980, I.C.J. Reports 1980, at paras 3, 5; Separate opinion of Judge Shahabuddeen, Maritime Delimitation in the Area between Greenland and Jan Mayen (Denmark v. Norway), Judgment of 14.6.1993, I.C.J. Reports 1993, at p. 195; Dissenting opinion of Vice-President Weeramantry, Legality of Use of Force (Serbia and Montenegro v. Belgium), Order of 2.6.1999, I.C.J. Reports 1999, at p. 184; Dissenting opinion of Judge ad hoc Van den Wyngaert, Arrest Warrant of 11.4.2000 (Democratic Republic of the Congo v. Belgium), Judgment of 14.2.2002, I.C.J. Reports 2002, at para. 35 . 
... as the aggressor, indirectly responsible - but ultimately responsible - for large numbers of deaths and widespread destruction in El Salvador apparently much exceeding that which Nicaragua has sustained, Nicaragua's hands are odiously unclean. Nicaragua has compounded its sins by misrepresenting them to the Court. Thus both on the grounds of its unlawful armed intervention in El Salvador, and its deliberately seeking to mislead the Court about the facts of that intervention through false testimony of it Ministers, Nicaragua's claims against the United States should fail. ${ }^{10}$

Judge Schwebel invoked the Diversion of Water from the Meuse case, holding that Nicaragua was asking the ICJ to order what amounted to a specific performance of a reciprocal obligation which it was not performing, and the Court should clearly have refused. ${ }^{11}$ Having analysed thoroughly the conduct of Nicaragua, Judge Schwebel was of the opinion that its illegal conduct

... should have been reason enough for the Court to hold that Nicaragua had deprived itself of the necessary locus standi to complain of corresponding illegalities on the part of the United States, especially because, if these were illegalities, they were consequential on or were embarked upon in order to counter Nicaragua's own illegality - in short were provoked by it. ${ }^{12}$

The ICJ remained silent on the principle of clean hands in Military and Paramilitary Activities in and against Nicaragua as well as in other cases in which the parties have discussed the possible application of the principle. ${ }^{13}$

10 Dissenting Opinion of Judge Schwebel, Military and Paramilitary Activities in and against Nicaragua (Nicaragua v. United States of America), I.C.J. Reports 1986, at para. 268.

11 Ibid., para. 269.

12 Ibid., para. 272.

13 See: Barcelona Traction, Light, and Power Company Limited (Belgium v. Spain) (New Application: 1962), Judgment of 5.2.1970, I.C.J. Reports 1970; Phosphate Lands in Nauru (Nauru v. Australia), Judgment of 26.6.1992, I.C.J. Reports 1992, at paras 37-38; LaGrand (Germany v. United States of America), Judgment of 27.6.2001, I.C.J. Reports 2001, at paras 61, 63; Avena and Other Mexican Nationals (Mexico v. United States of America), Judgment of 31.3.2004, I.C.J. Reports 2004, at paras 45-47; Oil Platforms (Islamic Republic of Iran v. United States of America), Judgment of 6.11.2003, I.C.J. Reports 2003, at paras 29-30; Legal Consequences of the Construction of a Wall in the Occupied Palestinian Territory, Advisory Opinion of 9.7.2004, I.C.J. Reports 2004, at paras 63-64; Ahmadou Sadio Diallo (Republic of Guinea v. Democratic Republic of the Congo), Judgment of 24.5.2007, I.C.J. Reports 2007. 
It may be fairly stated that the Court has never recognised the principle of clean hands as either a rule of customary international law or a general principle of law in terms of Article 38(1)(c) of its Statute. ${ }^{14}$ This finds further confirmation in the work of the International Law Commission, which decided that the principle of clean hands should not apply in the context of international responsibility and diplomatic protection. ${ }^{15}$ Thus, the principle of clean hands is not part of positive international law and remains nothing more than a domestic legal concept, applied mostly in the AngloAmerican tradition of equity. Nonetheless, the principle of clean hands may be enshrined in a positive rule of international law, and, therefore, its operation in international law rests on the application of such a rule. Thus, one must invoke a rule of international law which encompasses the concept of clean hands, allowing for the assertion that he who comes to court with unclean hands, with respect to the subject matter or the other party to a dispute, may not receive relief. A careful analysis of international law points to a conclusion that the principle of international law may be expressed in the following forms:

1) a ground of inadmissibility of a claim;

2) a defence on the merits, which results in exoneration or attenuation of responsibility;

3) contribution of the injured party which excludes or mitigates the obligation to make reparation (Articles 31 and 39 of the Articles on Responsibility of States for Internationally Wrongful Acts, or ARSIWA).

The purpose of the present article is to examine international investment law in order to ascertain whether the principle of clean hands could be effectively invoked in the context of investment treaties (bilateral or multilateral) if an investor violates human rights protected by international treaties while making and subsequently performing its investment. To this

14 See: B. Bollecker-Stern, La préjudice dans la théorie de la responsabilité internationale, Paris 1973, pp. 312, 315; Ch. Rosseau, Droit international public. Tome V. Les rapports conflictuels, Paris 1983, p. 170; J. Crawford, Second Report on State Responsibility, A.CN.4/498/ Add.2, 30.4.1999, at para. 334; G. Hafner, 2590. Meeting of the ILC, 18.6.1999, YILC 1999, vol. I, p. 167, at paras 55, 59; I. Brownlie, 2713. Meeting of the ILC, 1.5.2002, YILC 2002, vol. I, p. 13, at para. 6 .

15 Draft articles on responsibility of States for internationally wrongful acts, Report of the International Law Commission, 53 ${ }^{\text {rd }}$ Session, UN Doc. A/56/10, YILC 2001, vol. 2 (2), at p. 72, para. 9; Draft Articles on Diplomatic Protection with Commentaries, Report of the International Law Commission, $58^{\text {th }}$ Session, UN Doc. A/61/10. 
end, the remainder of this paper is structured in three parts. The firsts briefly examines whether or not and, if so, to what extent an investor is obliged to comply with internationally recognised human rights. The second part is devoted to the examination of investors' obligation to comply with domestic law while investing in a host State. It discusses, inter alia, investment awards that may be of relevance in future disputes concerning alleged violations of human rights by foreign investors. The final section features a set of observations contained in the form of a summary.

\section{Human Rights Obligations of Investors under International Law}

Human rights treaties do not impose obligations upon non-State actors, including foreign investing corporations. However, certain economic entities and, in particular, corporations have become global actors of such potential that they are able to dwarf the economies of many countries, wielding the power to influence international and domestic politics and regulations. Thus, it is not surprising that the international community has gradually begun to support the idea of imposing obligations in the field of internationally protected human rights upon corporations. S.R. Ratner gave three arguments in support of the thesis that the power of corporations requires moving beyond state responsibility. ${ }^{16}$ First, the desire of less developed States to welcome foreign investment means that some governments have neither the interest nor the resources to monitor corporate behaviour. Second, the government might use corporate resources to commit its own human rights violations. Third, corporations having such economic power and operating in many countries has become independent of governmental control. Thus, States may be incapable of introducing and enforcing regulations that would effectively restrain foreign investors in their conduct for the purpose of protecting human rights.

The present state of international relations and the economic power of some private actors necessitate taking action on an international plane. Since corporations are not direct duty holders, each State shall take the necessary steps to adopt such laws as may be required to give effect to

16 S.R. Ratner; Corporations and Human Rights: A Theory of Legal Responsibility; 'Yale Law Journal' 2001-2002, vol. 111, at pp. 443, 462-463. 
internationally recognised human rights. Under domestic law, it may impose, and enforce, duties on corporations, also with respect to the protection of human rights. In such circumstances, investors are indirectly obliged to respect human rights as reflected in the domestic law of a host State. However, the indirect obligations of corporations do not effectively meet the expectations of the international community as they fail to ensure adequate compliance with internationally protected human rights. Therefore, in recent years various proposals have been made and different soft law instruments have been adopted, so as to impose on individuals and, especially, on corporations, the obligation to respect human rights and introduce a regime of corporate responsibility for violations of such rights. The United Nations High Commissioner for Human Rights identified over 200 existing initiatives and standards relevant to corporate social responsibility. The Commissioner distinguished, inter alia, international instruments directed to States but relevant to business (such as the International Labour Organisation Tripartite Declaration of Principles concerning Multinational Enterprises and Social Policy and the OECD Guidelines for Multinational Enterprises), nationally based standards (e.g. United States Alien Tort Claims Act), certification schemes (including the Kimberley Process Certification Scheme), and voluntary initiatives, which were described in the following words:

[v]oluntary initiatives include codes of conduct, directives, policies, third-party, and self-reporting initiatives established by individual companies, groups of companies, intergovernmental organisations or civil society groups and adopted by business on a voluntary basis. The Secretary-General's United Nations Global Compact provides an example of a voluntary initiative backed by the United Nations. Intergovernmental voluntary initiatives include the Voluntary Principles on Security and Human Rights for the extractive and energy sectors and the Extractive Industries Transparency Initiative. Non-governmental voluntary initiatives include the Global Sullivan Principles, the Caux Round Table Principles for Business and International Peace Operations Associations Code of Conduct. In the consultation process, individual companies - BASF, BP, Gap, Nexen, Pfizer, Rio Tinto, Shell, SONOFON, Storebrand, and Telefonica - provided information on their voluntary initiatives. ${ }^{17}$

17 Report of the United Nations High Commissioner for Human Rights on the Responsibilities of Transnational Corporations and Related Business Enterprises with Regard to Human Rights, Report of the Sub-Commission on the Promotion and 
All these initiatives are accepted by corporations only on a voluntary basis. They are legally non-binding instruments, lacking any enforcement mechanism other than that of negative reactions of States, customers, and public opinion. They have been virtually ineffective at holding corporations responsible for violations of human rights obligations. ${ }^{18}$

The question concerning corporate responsibility has been dealt with by the United Nations. The first attempts to adopt a code of conduct for transnational corporations under the aegis of the UN were made in the 1970s and the 1980s. On 20.8.1998, the Sub-Commission on the Promotion and Protection of Human Rights established, for a three-year period, a sessional working group of the Sub-Commission "to examine the working methods and activities of transnational corporations." ${ }^{19}$ The SubCommission approved the Norms on the Responsibility of Transnational Corporations and Other Business Enterprises with Regard to Human Rights, which were subsequently transmitted to the Commission on Human Rights for consideration. ${ }^{20}$ According to the Commentary on the Norms, corporations have been placed under certain direct obligations, whose aim it is to ensure that human rights are respected. ${ }^{21}$

Protection of Human Rights, Commission on Human Rights, U.N. Doc. E/CN.4/2005/91, 15.2.2005, at para. 7 (d).

18 A. Adeyeye, Corporate Responsibility in International Law: Which Way to Go? 'Singapore Yearbook of International Law' 2007, vol. 11, at pp. 141-162; P. Dumberry, G. Dumas-Aubin, When and How Allegations of Human Rights Violations can be Raised in Investor-State Arbitration, 'The Journal of World Investment \& Trade' 2012, vol. 13, at pp. 349, 351-353; S. Picciotto, Rights, Responsibilities, and Regulation of International Business, 'Columbia Journal of Transnational Law' 2003-2004, vol. 42, at pp. 131, 139144; P. Muchlinski, Human Rights, Social Responsibility, and the Regulation of International Business: The Development of International Standards by Intergovernmental Organisations, 'Non-State Actors \& International Law' 2003, vol. 3, no 1, at pp. 123, 128; P. Simons, Corporate Voluntarism and Human Rights: The Adequacy and Effectiveness of Voluntary SelfRegulation Regimes, 'Industrial Relations' 2004, vol. 59, no 1, at pp. 101, 130; C.M. Vázquez, Direct vs. Indirect Obligations of Corporations Under International Law, 'Columbia Journal of Transnational Law' 2005, vol. 43, at pp. 927-959.

19 The Sub-Commission on the Promotion and Protection of Human Rights, resolution $1998 / 8$ of 20.8 .1998 .

20 Norms on the Responsibilities of Transnational Corporations and Other Business Enterprises with Regard to Human Rights, 14.8.2003, U.N. Doc. E/CN.4/Sub.2/2003/12/ Rev.2, hereinafter 'UN Norms'.

${ }^{21}$ Commentary on the Norms on the Responsibilities of Transnational Corporations and Other Business Enterprises with Regard to Human Rights, U.N. Doc. E/CN.4/ Sub.2/2003/38/Rev.2 (2003). For example, the Norms impose on companies: (i) the 
Shortly after the Norms had been accepted, the Commission on Human Rights adopted a resolution requesting the Secretary General to appoint a Special Representative on this issue for a term of two years. In 2011, J. Ruggie, the UN Special Representative, drafted the Guiding Principles on Business and Human Rights, recognising the corporate obligation to respect human rights, ${ }^{22}$ which were subsequently endorsed by the UN Human Rights Council. ${ }^{23}$ Principle 11 states that "business enterprises should respect human rights. This means that they should avoid infringing on the human rights of others and should address adverse human rights impacts with which they are involved." Corporate responsibility exists independently of States' abilities and willingness to respect human rights and the latter does not diminish the obligation of corporations. Principle 13 further provides that the responsibility to respect human rights requires business enterprises avoiding causing or contributing to adverse human rights impacts through their own activities, and to address such impacts as they occur and seek to prevent or mitigate adverse human rights impacts directly linked to their operations, products, or services offered by their business affiliates, even if they have not contributed to those impacts themselves. Such responsibility applies to all enterprises, including foreign investors in host States.

The Guiding Principles remain 'soft' law, as many other instruments devoted to the protection of human rights against abuses perpetrated by corporations. Bearing in mind the effective implementation and respect

responsibility to use due diligence in ensuring that their activities do not contribute directly or indirectly to human rights abuses, (ii) the responsibility to ensure that they do not benefit directly or indirectly from such abuses, and (iii) the responsibility to refrain from undermining efforts to promote and ensure respect for human rights. See: D. Weissbrodt and M. Kruger, Norms on the Responsibilities of Transnational Corporations and Other Business Enterprises with Regard to Human Rights, 'American Journal of International Law' 2003, vol. 97, at pp. 901-922.

22 Guiding Principles on Business and Human Rights: Implementing the United Nations 'Protect, Respect, and Remedy' Framework, Report of the Special Representative of the UN Secretary-General on the issue of human rights, transnational corporations, and other business enterprises, John Ruggie, U.N. Doc. A/HRC/17/31, 21.3.2011. See: D. Weissbrodt, Keynote Address: International Standard-Setting on the Human Rights Responsibilities of Business, 'Berkeley Journal of International Law' 2008, vol. 26, at pp. 373-391; A. Teitelbaum, Observations on the Final Report of the Special Representative of the UN Secretary General on the issue of human rights and transnational corporations and other business enterprises, John Ruggie, 'TLWNSI Issue Brief' May 2011, at pp. 1-10.

${ }^{23}$ Human Rights Council Res. 17/4, 6.7.2011, UN Doc. A/HRC/RES/17/4. 
of internationally recognised human rights, it seems appropriate to state that the conclusion of legally binding international agreements would be a welcome development in international law since it would impose direct human rights obligations on corporations. However, no such agreement has been concluded yet. The present state of international law with respect to human rights obligations imposed on individuals was discussed in the Kiobel v. Royal Dutch Petroleum case, ${ }^{24}$ in which the US Court of Appeal considered the sources of international law with respect to the existence of a norm of corporate responsibility. The Court arrived at the conclusion that

no corporation has ever been subject to any form of liability (whether civil, criminal, or otherwise) under the customary international law of human rights. Rather, sources of customary international law have, on several occasions, explicitly rejected the idea of corporate liability. Thus, corporate liability has not attained a discernible, much less universal, acceptance among nations of the world in their relations inter se. ${ }^{25}$

Therefore, although the international community aims to impress on corporations the respect of human rights, it is still necessary to look for alternative solutions, which already exist and which would enforce, albeit to a limited extent, the protection of human rights through direct obligations imposed upon individuals under international law and, particularly, pursuant to international investment law. It seems that one of the potential candidates remains the principle of clean hands, which has already been considered by arbitral tribunals, as the next sections will demonstrate.

Moreover, the transnational activity of multinational corporations is combined with the development of international criminal law. It seems that there are no conceptual stumbling blocks with regard to the application of international criminal law to multinational corporations. ${ }^{26}$ The

${ }^{24}$ Kiobel v. Royal Dutch Petroleum Co., United States Court of Appeals, Second Circuit, 17.9.2010, 621 F.3d 111 (2010). See also: Kiobel v. Royal Dutch Petroleum Co., US Supreme Court, 17.4.2013, 133 S.Ct. 1659 (2013).

${ }^{25}$ Kiobel v. Royal Dutch Petroleum Co., United States Court of Appeals, Second Circuit, 17.9.2010, 621 F.3d 111 (2010), at pp. 148-149.

26 See: J. Larik, Corporate International Criminal Responsibility: Oxymoron or an Effective Tool for 21 ${ }^{\text {st }}$ Century Governance?, [in:] (eds.) J. Hertwig, S. Maus, A. Meyer zu Schwabedissen \& M. Schuler, 'Global Risks - Constructing World Order through Law, Politics, and Economics', Peter Lang, Frankfurt am Main 2010, at pp. 119-142. See regarding the general issue of criminal liability of corporations: $C$. Chiomenti, Corporations and the International Criminal Court, [in:] O. De Schutter (ed.), 'Transnational Corporations 
complex and problematic question of criminal responsibility of multinational corporations concerns several basic issues. It includes forms of punishment applicable to corporations. For example, the Council of Europe proposed several penalties, ranging from a warning, reprimand, or fine to confiscation of property, removal of managers, appointment of provisional management, and closure of the enterprise. ${ }^{27}$ The corporate criminal responsibility should supplement individual criminal responsibility, and the company should be tried as an 'accessory' to the individual's crime. ${ }^{28}$ Such a regime would rectify the deficit in terms of corporate accountability by filling the gap that traditional approaches, such as classic state responsibility, human rights regime, and international humanitarian law, have been unable to bridge. ${ }^{29}$ What is more important, practice suggests that corporate criminal responsibility should be employed in cases of gross breaches of human rights committed by multinational corporations. In this regard, the dispute between Chevron and Ecuador may serve as a good example. Over the past five decades petroleum corporations, including Texaco (now owned by the Chevron Corporation), have come to Ecuador in search of oil. According to the 1993 report "Crudo Amazónico" (Amazon Crude) by the environmental lawyer Judith Kimerling, between 1972 and 1992, when the corporation left Ecuador, Texaco intentionally dumped more than 19 billion gallons of toxic wastewaters into the region and was responsible for 16.8 million gallons of crude oil spilling from the main pipeline into the forest. ${ }^{30}$ Moreover, according to another report, living in proximity to oil fields have increased the risk of residents developing health problems. ${ }^{31}$ These documents indicate serious human rights violations against people

and Human Rights', Hart Publishing, Oxford, Portland 2006; A. de Jonge, Transnational Corporations and International Law, Accountability in the Global Business Environment, Edward Elgar, Cheltenham 2011.

27 Recommendation No. R (88) 18 of the Committee of Ministers of Member States Concerning Liability of Enterprises Having Legal Personality for Offences Committed in the Exercise of Their Activities of 20.10.1988, Appendix, at pp. 7-8.

28 A. Clapham, The Question of Jurisdiction under International Criminal Law over Legal Persons, The Hague 2000, p. 153.

${ }^{29}$ J. Larik, Corporate..., op. cit., at p. 142.

30 J. Kimerling, Environmental Adult of Texaco's Amazon Oil Fields: Environmental Justice or Business as Usual, The Recent Developments, 'Harvard Human Rights Journal' 1994, vol. 7, at pp. 199-224.

31 See also: M.S. Sebastián, J.A. Córdoba, Yana Curi Report: The Impact of Oil Development on the Health of the People of the Ecuadorian Amazon, 1999, available at: https://chevrontoxico.com/assets/docs/yana-curi-eng.pdf, last access: 15.12.2015. 
living in the area where Texaco operated. The rights of the local population to the highest attainable standards of health, to an adequate standard of living, and to water and sanitation, have been infringed upon. In 1993, a group of Ecuadorian citizens filed a class action lawsuit with the US federal court and, subsequently, with the Ecuadorian courts. Eventually, on 12.11.2013, the National Court of Ecuador upheld the ruling against Texaco/Chevron for environmental damage, and ordered it to pay USD 9.51 billion in damages. In the meantime, Chevron filed an international arbitration claim with the Permanent Court of Arbitration, alleging that Ecuador violated the US-Ecuador BIT. This case is still pending. ${ }^{32}$

In October 2014, representatives of the victims submitted a communication to the International Criminal Court, demanding that the Prosecutor investigate the circumstances of the oil contamination in Ecuador. They argued that Chevron's actions should be construed of as crimes against humanity, and called for the ICC to assert its jurisdiction and investigate the conduct of the Chief Executive Officer of Chevron and any other corporate officers of the company. ${ }^{33}$ The Prosecutor relied on the ICC Statute to determine that, at the time, there was no basis to investigate the abovementioned communication. ${ }^{34}$

Although the ICC decided not to conduct an investigation, the Chevron case shows international criminal liability of corporate bodies would be one of the adequate remedies in this and similar cases. If the allegations had been substantiated, the requirements of justice would demand that, apart from individual responsibility, criminal responsibility be imposed upon corporations for violating human rights. There seems to be no persuasive reason to prevent the expansion of international criminal law to corporate bodies. What is more, the introduction of corporate criminal responsibility would be a welcome development, enhancing the overall protection of human rights at the international level. The above case demonstrates that bringing about the extension of international criminal law to corporate actors would serve the demands of justice and protection of human rights.

32 Chevron Corporation and Texaco Petroleum Company v. The Republic of Ecuador (PCA Case No. 2009-23). See for a more detailed description of this complex case: http:// business-umanrights.org/en/texacochevron-lawsuits-re-ecuador, last access: 15.12.2015.

33 Communication to the Office of the Prosecutor, available at: http://chevrontoxico. com/assets/docs/2014-icc-complaint.pdf, last access: 15.12.2015.

34 See: Letter of the office of the Prosecutor to R. Doak Bishop dated 16.3.2015, http:// freebeacon.com/wp-content/uploads/2015/04/ICC-letter.pdf, last access: 15.12.2015. 


\section{Protection of human rights under the principle of clean hands in international investment arbitration}

Consent to international investment arbitration may be limited by States. One investment tribunal rightly stated that "it is clear that States may specifically and expressly condition access of investors to a chosen dispute settlement mechanism, or the availability of substantive protection [...] one such common condition is an express requirement that the investment comply with the internal legislation of the host State." ${ }^{35}$ Investment treaties usually state that protection is granted to investments made in accordance with the law of the host State. Thus, investments made in breach of domestic law may not be protected under an investment treaty, and the claims of an investor alleging breaches of investment standards may be held inadmissible or rejected in the merits phase. The "investment made in accordance with law" clause may be regarded as a manifestation of the principle of clean hands. ${ }^{36}$ It should be noted that arbitral tribunals have already employed the principle of clean hands in their reasoning in order to determine the issue of jurisdiction or admissibility. In general, they held that an investment made not in accordance with the law may not be protected under the international investment regime. The analysis of these decisions should shed light on the question whether human rights may be protected under the "investment made in accordance with law" clause.

In recent years, the principle of clean hands has been invoked in investment cases. It seems that Saluka BV was the first case in which the Tribunal considered, at least to some extent, the principle of clean hands. The Respondent argued that Nomura, investor's parent company, had failed to disclose to the $C$ zech authorities, at the time of the purchase of its shares in IPB (Investični a Poštovní banka a.s.), the true purpose of the purchase, which was to facilitate its acquisition of the Czech breweries, Pilsner Urquell, in which IPB held a controlling shareholding. ${ }^{37}$ Therefore

35 Gustav F W Hamester GmbH \& Co KG v. Republic of Ghana, ICSID Case No. ARB/07/24, Award of 18.6.2010, para. 125.

36 R. Moloo, A Comment on the Clean Hands Doctrine in International Law, 'Transnational Dispute Management' 2011, vol. 8, no 1, at pp. 1, 6; P. Dumberry, G. Dumas-Aubin, The Doctrine of "Clean Hands" and the Inadmissibility of Claims by Investors Breaching International Human Rights Law, 'Transnational Dispute Management' 2013, vol. 10, no 1, at pp. 1, 4.

37 Saluka Investments BV (The Netherlands) v. the Czech Republic, PCA, UNCITRAL, Partial Award of 17.3.2006, at para. 174. 
Saluka, to whom Nomura had transferred its IPB shareholding, was precluded from having recourse to arbitration under the bilateral investment treaty (BIT). However, the Tribunal was unable to conclude that the circumstances of the original purchase of the shares by Nomura Europe had been shown to involve any breach of the law by Nomura, such as to warrant its purchase of IPB shares being considered an unlawful investment and, in consequence, not entitled to protection under the BIT. ${ }^{38}$ In other words, it held that the investment was made in accordance with the law of the host State. Accordingly, the Tribunal was of the opinion that:

there are no good reasons for declining to consider the Claimant's holding of IPB shares in issue in this case to be an 'investment' within the meaning of the definition of that term in Article 1 of the Treaty. ${ }^{39}$

The tentative conclusion stemming from the award is that the principle of clean hands may not be invoked if an investor did not violate the law of the host State at the time of making the investment at issue.

In another case, the Tribunal upheld the objection of the Respondent to the effect that the national law of El Salvador had been breached. Inceysa Vallisoletana obtained a concession contract for vehicle inspection services in El Salvador by committing fraud in the public bidding process. ${ }^{40}$ The host State argued that its consent to arbitration did not cover disputes concerning investments made in breach of domestic law. The Tribunal agreed with El Salvador and added that travaux préparatoires without any doubt indicated that "the will of the parties to the BIT [El Salvador and Spain] was to exclude from the scope of application and protection of the Agreement disputes originating from investments which were not made in accordance with the laws of the host State." It also held that the investment violated the principles of good faith, of nemo auditur propriam turpitudinem allegans, and of international public policy. ${ }^{41}$ The Latin maxim is connected with another six maxims that, in the view of arbitrators, clearly applied to that case. ${ }^{42}$ One of them, ex dolo malo non oritur actio, provides that:

$38 \quad$ Ibid., at para. 217.

39 Ibid., at para. 221.

40 Inceysa Vallisoletana, S.L. v. Republic of El Salvador, Award of 2.8.2006, ICSID Case No. ARB/03/26.

41 Ibid., at paras 230-252.

42 Ibid., at para. 240. The Tribunal identified the following maxims: (a) "Ex dolo malo non oritur actio" (an action does not arise from fraud); (b) "Malitiis nos est indulgendum" (there must be no indulgence for malicious conduct); (c) "Dolos suus neminem relevat" 
... the foreign investor cannot seek to benefit from an investment effectuated by means of one or several illegal acts and, consequently, enjoy the protection granted by the host State, such as access to international arbitration to resolve disputes, because it is evident that its act had a fraudulent origin and, as provided by the legal maxim, "nobody can benefit from his own fraud." ${ }^{43}$

The clear and obvious evidence of the violations committed by Inceysa during the bidding process led the Tribunal to the conclusion that the investor could not enjoy the protection under the BIT since

[a]llowing Inceysa to benefit from an investment made clearly in violation of the rules of the bid in which it originated would be a serious failure of the justice that this Tribunal is obligated to render. No legal system based on rational grounds allows the party that committed a chain of clearly illegal acts to benefit from them. ${ }^{44}$

Consequently, the Tribunal found that it did not have jurisdiction to hear the matter and that the Arbitral Tribunal was not competent to resolve it. Again, the arbitrators expressed the view that a breach of the law of the host State by an investor excludes its investment from the protection established under the BIT. It is also worth noting that the principle requiring investments to be made in accordance with law may be inferred from the will of the parties to a BIT.

In another case, World Duty Free, the investor obtained a contract by paying a significant bribe to the Kenyan President. ${ }^{45}$ The Tribunal held that:

[i]n light of domestic laws and international conventions relating to corruption, and in light of the decisions taken in this matter by courts and arbitral tribunals, this Tribunal is convinced that bribery is contrary to the international public policy of most, if not all, States or, to use another formula, to transnational public policy. Thus,

(no one is exonerated from his own fraud); (d) "In universum autum haec in ea re regula sequenda est, ut dolos omnimodo puniatur" (in general, the rule must be that fraud shall always be punished); (e) "Unusquique doli sui poenam sufferat" (each person must bear the penalty for his fraud), and (f) "Nemini dolos suusprodesse debet" (nobody must profit from his own fraud).

43 Ibid., at para. 242.

44 Ibid., at para. 244.

45 World Duty Free Company Limited v. The Republic of Kenya, Award of 4.10.2006, ICSID Case No. ARB/00/7. See: Metal-Tech Ltd. v. Republic of Uzbekistan, Award of 4.10.2013, ICSID Case No. ARB/10/3, passim, and, especially, at paras 110 (iii), 373-373. 
claims based on contracts of corruption or on contracts obtained by corruption cannot be upheld by this Arbitral Tribunal. ${ }^{46}$

Domestic laws applicable in the case were English and Kenyan law (being materially identical on the question of bribery). On the specific facts of this case, the Tribunal concluded that "the Claimant is not legally entitled to maintain any of its pleaded claims in these proceedings on the ground of ex turpi causa non oritur actio." ${ }^{47}$ It needs to be highlighted that the Tribunal applied the maxim, since the investment was made in breach of domestic and international law. Thus, the investor was deprived of legal protection under the BIT.

In the Fraport case, the Tribunal also reviewed the legality of the investment. ${ }^{48}$ Fraport exercised managerial control over a Philippine company, PIATCO, which had been awarded a concession to build and operate an airport terminal in Manila. It was proved that the investor had secretly managed and controlled its project in a manner that it knew was not in accordance with Philippine law, as Fraport had concluded that it was the only conceivable way for its investment to prove profitable. ${ }^{49}$ The arbitrators found that the conduct of the foreign investor was "egregious," and it could not "benefit from presumptions which might ordinarily operate in favour of the investor," such as the "construing of jurisdiction ratione materiae in a more liberal way which is generous to the investor." ${ }^{50}$ Although BITs oblige host States to conduct their relations with foreign investors in a transparent fashion, there are "some reciprocal if not identical obligations" binding on the foreign investor. One of them is "the obligation to make the investment in accordance with the host state's law." ${ }^{11}$ Therefore, the Tribunal concluded that:

[c]ompliance with the host state's laws is an explicit and hardly unreasonable requirement in the Treaty and its accompanying Protocol. Fraport's ostensible purchase of shares in the Terminal 3 project, which concealed a different type of unlawful investment, is not an

46 World Duty Free Company Limited v. The Republic of Kenya, Award of 4.10.2006, ICSID Case No. ARB/00/7, at para. 157.

47 Ibid., at para. 179.

48 Fraport AG Frankfurt Airport Services Worldwide v. Republic of the Philippines, Award of 16.8.2007, ICSID Case No. ARB/03/25.

49 Ibid., at paras 397-398.

50 Ibid., at paras 396-397.

51 Ibid., at para. 402. 
"investment" which is covered by the BIT. As the BIT is the basis of jurisdiction of this Tribunal, Fraport's claim must be rejected for lack of jurisdiction ratione materiae. ${ }^{52}$

Although the Tribunal mentioned neither the principle of clean hands nor any of Latin maxims invoked in previous cases, it applied the "investment made in accordance with law" clause, since Fraport knowingly and intentionally circumvented domestic law by means of secret shareholder agreements. Consequently, the Tribunal rightly concluded that the investor could not claim to have made its investment in accordance with the law of the host State. ${ }^{53}$ Moreover, the Tribunal applied the clause to the performance of the investment after it had been made. It, therefore, appears that the clause covers both the legality at the initiation of the investment and the legality during the subsequent performance of the investment.

In Rumeli Telekom v. Republic of Kazakhstan, the Respondent alleged that the sole purpose of the Claimants' investment was to further its worldwide fraud and, thus, the investment was not in conformity with the laws of Kazakhstan. The host State argued that the Tribunal should adopt the same approach as the Inceysa Tribunal, which identified three general principles of international law against which the conduct of the claimant must be compared: good faith, nemo auditur propriam turpitudinem allegans, and international public policy. As a consequence, the Respondent contended that it did not consent to ICSID jurisdiction over this dispute because the Claimants' investments were not legal and violated the principle of good faith, the principle nemo auditur propriam turpitudinem allegans, and international public policy. ${ }^{54}$

The Tribunal agreed with the Respondent that in order to receive the protection of a bilateral investment treaty, the disputed investment had to be in conformity with the host State laws and regulations. At the same time, it reiterated the finding reached by the arbitral Tribunal in the L.E.S.I. case that "investments in the host State will only be excluded from the protection of the treaty if they have been made in breach of

52 Ibid., at para. 404.

53 Ibid., at para. 401.

54 Rumeli Telekom A.S. and Telsim Mobil Telekomunikasyon Hizmetleri A.S. v. Republic of Kazakhstan, Award of 29.7.2008, ICSID Case No. ARB/05/16, at paras 235, 310. 
fundamental legal principles of the host country. ${ }^{.55}$ However, in the case at issue, the Respondent failed to demonstrate that the investment was fraudulent or violated any laws or regulations of Kazakhstan. ${ }^{56}$ As a result, the Tribunal decided that the Claimants were entitled to arbitration and that the Tribunal had jurisdiction to hear the dispute under Article 25 of the ICSID Convention in conjunction with Article 7 of the Turkey-Kazakhstan BIT. ${ }^{57}$ Nevertheless, it may be reasonably assumed that if the Respondent had proved allegation of fraud perpetrated by the investor, the Tribunal would have applied the "investment made in accordance with law" clause by invoking the principle of nemo auditur propriam turpitudinem allegans or international public policy.

In the context of the principle of clean hands and its emanation, the "investment made in accordance with law" clause, the Plama Consortium Limited v. Republic of Bulgaria seems to be of particular importance, since it was deliberated under the Energy Charter Treaty, which does not contain a provision requiring the conformity of the investment with any particular law. ${ }^{58}$ Nevertheless, the Tribunal expressed the view that this was not tantamount to the protections provided for by the ECT covering all kinds of investments, including those contrary to domestic or international law. Bearing in mind the rules concerning the application and interpretation of treaties as well as the introductory note to the ECT, which states that "[t]he fundamental aim of the Energy Charter Treaty is to strengthen the rule of law on energy issues," the Tribunal found that the ECT should be interpreted in a manner consistent with the aim of encouraging respect for the rule of law. Therefore, the Arbitral Tribunal concluded that "the

55 Ibid., para. 319. L.E.S.I. S.p.A. and ASTALDI S.p.A. v. République Algérienne Démocratique et Populaire, Decision of 12.7.2006, ICSID Case No. ARB/05/3, at para. 83 (iii). See also: Tokios Tokelés v. Ukraine, Decision on Jurisdiction of 29.4.2004, ICSID Case No. ARB/02/18, at para. 84; Desert Line Projects LLC v. The Republic of Yemen, Award of 62.2008, ICSID Case No. ARB/05/17, at para. 104. In Saba Fakes v. Republic of Turkey, Award of 14.7.2010, ICSID Case No. ARB/07/20, at para. 119, the Tribunal decided otherwise and held that "the legality requirement contained therein concerns the question of the compliance with the host State's domestic laws governing the admission of investments in the host State."

56 Rumeli Telekom A.S. and Telsim Mobil Telekomunikasyon Hizmetleri A.S. v. Republic of Kazakhstan, Award of 29.7.2008, ICSID Case No. ARB/05/16, at paras 320-322.

57 Ibid., at para. 331.

58 Plama Consortium Limited v. Republic of Bulgaria, Award of 27.8.2008, ICSID Case No. ARB/03/24, at para. 138. 
substantive protections of the ECT cannot apply to investments that are made contrary to law." 59

As a consequence, the Tribunal, having previously established that the investment had been "the result of a deliberate concealment amounting to fraud, calculated to induce the Bulgarian authorities to authorise the transfer of shares" ${ }^{\prime 0}$ and in light of the ex turpi causa defence, could not lend its support to the Claimant's request nor could it grant the substantive protections of the ECT. ${ }^{61}$ It should be stressed that the Plama Tribunal considered and applied the ex turpi causa defence even though the ECT does not contain an explicit "investment made in accordance with law" clause. However, by employing the rules concerning the application and interpretation of treaties, the Tribunal came to a reasonable conclusion that regardless of the wording of the ECT each investor has to abide by domestic and international law. Thus, it might be reasonably concluded that the "investment made in accordance with law" clause is a general principle of international investment law which does not allow for granting legal protection to investments made contrary to law.

Another Tribunal confirmed the finding of the Inceysa and Plama Tribunals and affirmed the principle that "the conformity of the establishment of the investment with the national laws - is implicit even when not expressly stated in the relevant BIT,"62 although the BIT between the Czech Republic and Israel was expressly limited to investments made in accordance with the laws and regulations of the host State. The Tribunal correctly emphasised that the purpose of international protection through ICSID arbitration cannot be granted to investments that are made contrary to law. ${ }^{63}$ Considering the legal effects of violations of the law in the light of stages of arbitral proceedings, the Tribunal held that:

[t]he fact that an investment is in violation of the laws of the host State can be manifest and will therefore allow the tribunal to deny its jurisdiction. Or, the fact that the investment is in violation of the laws of the host State can only appear when dealing with the merits, whether it was not known before that stage. In any event, the Tribunal

59 Ibid., at para. 139.

Ibid., at paras 128-129, 134-135.

61 Ibid., at para. 149.

62 Phoenix Action, Ltd. v. The Czech Republic, Award of 15.4.2009, ICSID Case No. ARB/06/5, at para. 101.

63 Ibid., at para. 102. 
notes that such requirement is expressly stated in the Israel/Czech Republic BIT or whether the tribunal considered it best to be analysed at the merits stage, like in the case of Plama...

the requirement of the conformity with law is important in respect of the access to the substantive provisions on the protection of the investor under the BIT. This access can be denied through a decision on the merits. However, if it is manifest that the investment has been performed in violation of the law, it is in line with judicial economy not to assert jurisdiction. ${ }^{64}$

The Tribunal thus observed that the breach of law by an investor may be upheld either in the jurisdiction/admissibility or the merits phase, depending upon the circumstances of a given case. Manifest violation of law should constitute a basis for dismissal of a claim at the jurisdiction stage, due to judicial economy. It is true that circumstances may dictate considering the breach of law in the merits phase, but it ought to be remembered that it is primarily the violation of the law by an investor making the investment that decides whether a particular investment claim is admissible at all and, therefore, in principle access to substantive protection should be denied in the jurisdiction/admissibility phase as opposed to the Phoenix decision, which might suggest otherwise. ${ }^{65}$

In Siag, the Respondent unsuccessfully invoked the principle of clean hands with respect to the conduct of the Claimant during the arbitral procedure. Egypt contended that the investor had fraudulently concealed from Egypt and the Tribunal the re-opening of his bankruptcy and submitted that he could not then claim that Egypt had waived its objections that would have been based on that re-opening. ${ }^{66}$ The Tribunal, however, found that Egypt had both actual and constructive knowledge of the 2003 re-opening of the bankruptcy proceedings involving Mr Siag. ${ }^{67}$ Thus, arbitrators did not uphold and apply the principle of clean hands, but based their award on procedural time-limits. Nonetheless, it might be reasonably assumed that the Tribunal would have at least considered the principle if the factual background of the case had been proved to be in favour of the Egyptian claim.

64 Ibid., at para. 102 [footnote omitted].

65 See also: R. Moloo, op. cit., p. 9.

66 Waguih Elie George Siag and Clorinda Vecchi v. The Arab Republic of Egypt, Award of 1.6.2009, ICSID Case No. ARB/05/15, at para. 163.

67 Ibid., at para. 203. 
In Hamester, the Tribunal considered whether the conduct of the investor fell within the scope of investment protection granted under the Ghana-Germany BIT. It made a general observation to the effect that:

an investment will not be protected if it has been created in violation of national or international principles of good faith; by way of corruption, fraud, or deceitful conduct; or if its creation itself constitutes a misuse of the system of international investment protection under the ICSID Convention. It will also not be protected if it is made in violation of the host State's law. ${ }^{68}$

In the opinion of the Tribunal, these are the general principles which exist independently of specific wording to this effect in a BIT. ${ }^{69}$ The Tribunal did not include the obligation to respect human rights as one of the principles, but it might at least be worth considering whether the protection of human rights should be regarded as one of such independent general principles. In the further part of the Award, however, the Tribunal explained that the clean hands of an investor should be analysed only if any of the acts complained of gives rise to or could have given rise to an international responsibility of the host State. ${ }^{70}$ This observation should be endorsed to a certain extent since a lack of clean hands belongs also to the admissibility phase and, as such, debars arbitral tribunals from considering the merits of the case. It is, therefore, to be observed that only if an investor has made its investment in accordance with the law does it become appropriate to analyse in detail the host State's behaviour and allegations of a breach of investment protection guaranteed under an investment treaty. In the case at hand, the Tribunal did not have to address the Respondent's defences based on the alleged fraudulent acts and violations of fiduciary duties by the Claimant during the life of the investment because Ghana had incurred no responsibility under the BIT. ${ }^{1}$

The last case which demands particular attention in light of the principle of clean hands concerns the Niko investment in Bangladesh. ${ }^{72}$

68 Gustav F W Hamester GmbH \& Co KG v. Republic of Ghana, Award of 18.6.2010, ICSID Case No. ARB/07/24, at para. 123.

69 Ibid., at para. 124.

70 Ibid., at para. 317.

71 Ibid., ai para. 350.

72 Niko Resources (Bangladesh) Ltd. v. Bangladesh Petroleum Exploration \& Production Company Limited ("Bapex") and Bangladesh Oil Gas and Mineral Corporation, Decision on Jurisdiction of 19.8.2013, ICSID Case No. ARB/10/11. 
It was the argument of the Respondent that Niko had committed acts of corruption and, as a consequence, it could not benefit from the agreements in general and from the ICSID arbitration clause in particular. ${ }^{73}$ The Claimant did not bring its claim with clean hands and, moreover, it was not affected by the question whether or not its bribery had achieved its admitted purpose. ${ }^{74}$ Before answering this question, the Tribunal made a number of general comments. Firstly, it observed that the principle of clean hands is known as part of equity in common law countries and the question whether the principle forms part of international law remains controversial while its precise content remains ill defined. ${ }^{75}$ Secondly, it noted the controversy over whether the principle is a rule of customary international law or a general principle of law. ${ }^{76}$ Thirdly, the Tribunal observed that it had been argued that

the clean hands doctrine, without express mention of the term, has found application in a number of other cases where claims were dismissed for lack of jurisdiction or as inadmissible because they were obtained fraudulently or were not in accordance with the law of the host State. ${ }^{77}$

Fourthly, in the context of the substantive content of the principle, the Tribunal quoted the Individual Opinion of Judge Hudson, G. Fitzmaurice and the Guyana v. Suriname case, in order to refer to three criteria of the principle of clean hands identified in the Guyana v. Suriname case. ${ }^{78}$ Finally,

73 Ibid., at para. 373.

74 Respondents' Response to the Claimant's Presentation of its Position with respect to the Request for the Compensation Declaration, Niko Resources (Bangladesh) Ltd. v. Bangladesh Petroleum Exploration \& Production Company Limited ("Bapex") and Bangladesh Oil Gas and Mineral Corporation, 28.9.2011, at para. 53; Respondents' letter of 29.8.2011, responding to the Tribunal's letter of 26.8.2011, Niko Resources (Bangladesh) Ltd. v. Bangladesh Petroleum Exploration \& Production Company Limited ("Bapex") and Bangladesh Oil Gas and Mineral Corporation.

75 Niko Resources (Bangladesh) Ltd. v. Bangladesh Petroleum Exploration \& Production Company Limited ("Bapex") and Bangladesh Oil Gas and Mineral Corporation, Decision on Jurisdiction of 19.8.2013, ICSID Case No. ARB/10/11, at para. 477.

76 Ibid., at para. 478.

77 Ibid., at para. 481.

78 Individual Opinion by Mr Hudson, Diversion of Water from the Meuse, PCIJ Publ., Series A/B, No. 70,at p. 77; G. Fitzmaurice, op. cit.; Guyana v. Suriname, PCA, Award of 17.9.2007 r., at paras $418,420-421$. 
it concluded that the aforementioned criteria had not been met and dismissed the arguments of the Respondent. In the Tribunal's view

the violation on which the Respondents rely is not continuing, but consisted in two acts that have been completed long ago; the remedy which the Claimant seeks does not concern protection against this past violation; and there is no relation of reciprocity between the relief which the Claimant now seeks in this arbitration and the acts in the past which the Respondents characterise as involving unclean hands. $^{79}$

The Niko case has been the first investment dispute in which the Arbitral Tribunal employed the phrase the "principle of clean hands." The Tribunal did not reject the application of the principle as such in international investment law; however, the facts of the case did not allow the Tribunal to apply the principle. To a large extent, the arbitrators followed the reasoning of Judge Hudson and the UNCLOS Tribunal. Nevertheless, M.O. Hudson and the UNCLOS Tribunal discussed the principle of reciprocity and the exception inadempleti contractus as a countermeasure rather than the principle of clean hands. Nonetheless, the decision in the Niko v. Bangladesh case points to the conclusion that a violation of the law of the host State is the basis of inapplicability of investment claims and results in lack of investment protection. Thus, the application of the principle of clean hands relies on the very obligation imposed upon the investor to respect the law of the host State.

The principle of clean hands has been discussed most recently in the three awards rendered in the arbitration between the majority shareholders of Yukos and the Russian Federation. ${ }^{80}$ The Russian authorities considered the conduct of Yukos to be tax abuse or tax evasion, as they were questioning the legality of Yukos' tax optimisation scheme. ${ }^{81}$ The Tribunal held

79 Niko Resources (Bangladesh) Ltd. v. Bangladesh Petroleum Exploration \& Production Company Limited ("Bapex") and Bangladesh Oil Gas and Mineral Corporation, Decision on Jurisdiction of 19.8.2013, ICSID Case No. ARB/10/11, at para. 483.

80 Hulley Enterprises Limited (Cyprus) v. The Russian Federation, UNCITRAL, PCA Case No. AA 226, Yukos Universal Limited (Isle of Man) v. The Russian Federation, UNCITRAL, PCA Case No. AA 227, Veteran Petroleum Limited (Cyprus) v. The Russian Federation, UNCITRAL, PCA Case No. AA 228, Final Awards of 18.7.2014, at para. 4 (hereinafter: Yukos cases). The proceedings in the above cases were joint and decided by the same Tribunal, which delivered three virtually identical Awards in all three cases on the same day.

81 See: ibid., at para. 272-502. 
that the "primary objective of the Russian Federation was not to collect taxes but rather to bankrupt Yukos and appropriate its valuable assets" ${ }^{82}$ and that the Russian Federation expropriated the Claimants' investment in violation of Article 13 of the ECT. ${ }^{83}$ Moreover, the Russian Federation breached the fair and equitable treatment standard covered by Article 10(1) of the $\mathrm{ECT}^{84}$ as well as the obligation not to impair by any unreasonable or discriminatory measures management, maintenance, use, enjoyment, or disposal of investment, as required by Article 10(1) of the ECT. ${ }^{85}$ The Respondent, however, submitted that the unclean hands of the Claimants deprived the Tribunal of jurisdiction, rendered the investment claims inadmissible and/or deprived the Claimants of the substantive protections of the ECT ${ }^{86}$ In order to decide on this objection, the arbitrators considered it appropriate to discuss the principle of clean hands in the following three sections: (a) can the principle of clean hands or legality requirement be read into the ECT? (b) does the clean hands doctrine constitute a general principle of law? (c) would any instances of claimants' alleged "bad faith and illegal" conduct be caught by a legality requirement read into the ECT?

The Yukos Tribunal correctly noted that:

even where the applicable investment treaty does not contain an express requirement of compliance with host State laws..., an investment that is made in breach of the laws of the host State may either: (a) not qualify as an investment, thus depriving the tribunal of jurisdiction; or (b) be refused the benefit of the substantive protections of the investment treaty. ${ }^{87}$

Consequently, the Tribunal held that an investment may not be protected if it has been made in violation of the host State's law or by an investor acting in bad faith. This principle exists independently of the specific wording of an investment treaty. These treaties impose obligations on States to treat investors in a fair and transparent fashion while, at the same time, they seek to encourage legal and bona fide investments. ${ }^{88}$

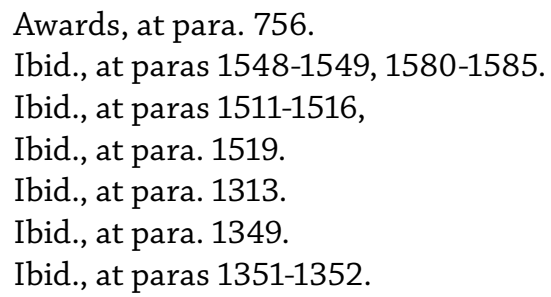


In response to the second argument, the Tribunal found that the principle of clean hands is not a general principle of law. ${ }^{89}$ According to the Tribunal, "[g]eneral principles of law require a certain level of recognition and consensus." ${ }^{90}$ Regrettably, it did not explain how to understand the notions of recognition and consensus as criteria of general principles. Finally, with respect to the third argument, the Tribunal held that a claimant may be barred from seeking relief under the ECT if its investment was made in bad faith and in violation of domestic law. ${ }^{91}$

In conclusion, the Tribunal found the Respondent's unclean hands argument to be unsubstantiated as "it does not operate to deprive the Tribunal of its jurisdiction in this arbitration, render inadmissible any of the Claimants' claims or otherwise bar Claimants' from invoking the substantive protections of the ECT. ${ }^{92}$ However, it pointed out that "some of the instances of Claimants' 'illegal or bad faith' conduct... could have an impact on the Tribunal's assessment of liability and damages." ${ }^{93}$ Therefore, a breach of the host State's law may be a defence to claimed substantive violations. It may exonerate or attenuate responsibility (l'atténuation ou l'exonération de la responsabilité) as well as exclude or reduce the obligation to pay reparation. Hence, the principle of clean hands, while not being a proper legal principle in international law, may be embodied in certain legal concepts. The principle finds its emanation in those concepts, a fine example of which is contributory fault. This was, indirectly, the argument of the Responded contending that the Claimants may not recover from the Russian Federation the fruits of their own wrongdoing since it did not establish that their loss had been caused by the Russian Federation's actions in violation of its obligations under the ECT. ${ }^{94}$

There are two Articles in the ILC Articles on State Responsibility which deal with the question of contributory fault and which were quoted by the Tribunal. They provide as follows:

Article 31. Reparation

1. The responsible State is under an obligation to make full reparation for the injury caused by the internationally wrongful act.

89 Awards, at para. 1358.

90 Ibid., at para. 1359.

91 Ibid., at para. 1364.

92 Ibid., at para. 1373.

93 Ibid., at para. 1374.

94 Awards, at paras 1594-1595. 
2. Injury includes any damage, whether material or moral, caused by the internationally wrongful act of a State. ${ }^{95}$

Article 39. Contribution to the injury

In the determination of reparation, account shall be taken of the contribution to the injury by willful or negligent action or omission of the injured State or any person or entity in relation to whom reparation is sought. ${ }^{96}$

The Tribunal observed, on the basis of the above provisions, that it must determine whether there was a sufficient causal link between a willful or negligent act or omission of the Claimants and the loss that Claimants ultimately suffered at the hands of the Russian Federation in the destruction of Yukos. Only contribution that is material and significant can trigger a finding of contributory fault. The PCA Tribunal highlighted that it had a wide margin of discretion in allocating the fault. ${ }^{97}$

In this regard, the Tribunal observed that, first of all, the legal concept of contributory fault must not be confused with the investor's duty to mitigate its losses. ${ }^{98}$ Second, in certain cases the contributory fault of the investor, while it may have increased the loss which it sustained, was unrelated to the wrongdoing of the State; i.e. the fault of the investor contributed to the losses which flowed from the wrongful act of the State..$^{99}$ Last, there have been certain decisions where the tribunals found that the

95 The ILC Commentary to this Article includes the following: "[i]t is true that cases can occur where an identifiable element of injury can properly be allocated to one of several concurrently operating causes alone. But unless some part of the injury can be shown to be severable in causal terms from that attributed to the responsible State, the latter is held responsible for all the consequences, not being too remote, of its wrongful conduct."

96 The ILC Commentary to Article 39 states that: "Article 39 deals with the situation where damage has been caused by an internationally wrongful act of a State, which is accordingly responsible for the damage in accordance with Articles 1 and 28, but where the injured State, or the individual victim of the breach, has materially contributed to the damage by some willful or negligent act or omission."

97 Awards, at paras 1599-1600.

98 Ibid., at para. 1603, referring to EDF International S.A. and Ors v. Argentine Republic, ICSID, ARB/03/23, Award of 11.6.2012, at para. 1301. See also: Middle East Cement Shipping and Handling Co. S.A. v. Arab Republic of Egypt, ICSID, ARB/99/6, Award of 12.4.2002; AIG Capital Partners, Inc and Anor v. Republic of Kazakhstan, ICSID, ARB/01/6, Award of 7.10.2003.

${ }^{99}$ Ibid., at para. 1604, referring to MTD Equity Sdn. Bhd. and MTD Chile S.A. v. Republic of Chile, ICSID Case No. ARB/-1/07, Award of 25.5.2004, and Iurii Bogdanov, 
victim contributed to the State's wrongdoing. ${ }^{100}$ Next, the Tribunal decided that there was a sufficient causal link between Yukos' abuse of the system in some of the low-tax regions and its demise, which triggered a finding of contributory fault on the part of Yukos. ${ }^{101}$ In the view of the Tribunal, the "Claimants should pay a price for Yukos' abuse of the low-tax regions by some of its trading entities... which contributed in a material way to the prejudice which they subsequently suffered at the hands of the Russian Federation." ${ }^{102}$ Having considered and weighed all the arguments, the Tribunal found that "as a result of the material and significant misconduct by the Claimants and by Yukos, the Claimants contributed to the extent of $25 \%$ to the prejudice which they suffered. Thus, the resulting apportionment of contribution to the injury as between the Claimants and the Respondent, namely $25 \%$ and $75 \%$, was regarded by Tribunal as fair and reasonable in the overall circumstances of the case."103

Thus, the contribution to injury amounting to a breach of law may function as a criterion reducing the damages. It reflects the principle of proportionality, i.e. the damage will be reduced proportionally to the contribution of the claimant. The conclusion reached by the Tribunal seems to be reasonable, and it reflects the principle of clean hands, as it allows us to evaluate the conduct of investors, with special regard to their violations of domestic law. Therefore, material and significant contribution to the injury suffered may be regarded as an emanation of the principle of clean hands. The causal link between the conduct of the investor and the injury suffered determines the amount of damages and affects the scope of responsibility of the host State.

The review of international investment awards points to a conclusion that there is a general principle of international investment law which does

Agurdino-Invest Ltd. and Agurdino-Chimia JSC v. Republic of Moldova, SCC Rules, Award of 22.9.2005.

100 Ibid., at para. 1605, referring to Antoine Goetz \& Consorts et S.A. Affinage des Metaux v. Republique du Burundi, ICSID, ARB/01/2, Award of 21.6.2012, and Occidental Petroleum Corporation and Occidental Exploration and Production Company v. Republic of Ecuador, ICSID, ARB/06/111, Award of 5.10.2012.

101 Ibid., at paras 1610-1632.

102 Ibid., at para. 1634.

103 Ibid., at para. 1637. See also: MTD Equity Sdn Bhd. v. The Republic of Chile, ICSID Case No. ARB/01/7, Decision on Annulment, 21.3.2007, at para. 101; Occidental Petroleum Corporation and Occidental Exploration and Production Company v. The Republic of Ecuador, ICSID Case No. ARB/06/11, Award of 5.10.2012, at paras 659-687. 
not allow one to grant legal protection to investments made contrary to the law of the host State. ${ }^{104}$ Such an obligation imposed upon investors does not need to be explicitly stated in an investment treaty. The application of the principle of clean hands rests upon the aforementioned general principle. It thus confirms that the principle of clean hands does not have an autonomous character and that it is enshrined in the obligation to make investments in accordance with law. It needs to be emphasised that the principle of clean hands in the form of a plea of illegality may result in lack of jurisdiction, inadmissibility of investment claims, or rejection of such claims in the merits phase. It depends on the timing of the illegality. All cases discussed above show that the plea of illegality concerned the time when an investment was made or the way it was subsequently conducted. Bearing in mind this temporal line, it could be argued that, in principle, unlawful conduct pertaining to making an investment is relevant to the jurisdiction/admissibility phase, whereas subsequent unlawful conduct is an issue related to the merits. ${ }^{105}$ Thus, any violation of the law of the host State that occurs once the investment has been made, "might be a defence to claimed substantive violations of the BIT, but could not deprive a tribunal acting under the authority of the BIT of its jurisdiction."106

104 See also: Salini Costruttori S.p.A. and Italstrade S.p.A. v. Kingdom of Morocco, Decision on Jurisdiction of 23.7.2001, ICSID Case No. ARB/00/4, at para. 45; Railroad Development Corporation v. Republic of Guatemala, Second Decision on Objections to Jurisdiction of 18.5.2010, ICSID Case No. ARB/07/23, at para. 146 (the Respondent was precluded from raising an objection to the Tribunal's ratione materiae jurisdiction since it knowingly overlooked alleged violation of its own law); Alpha Projektholding GmbH v. Ukraine, Award of 8.11.2010, ICSID Case No. ARB/07/16, at paras 298-302; SAUR International SA v. Republic of Argentina, Decision on Jurisdiction and Liability of 6.6.2012, ICSID Case No. ARB/04/4, at paras 310-312; Quiborax S.A., Non Metallic Minerals S.A. and Allan Fosk Kaplún v. Plurinational State of Bolivia, Decision on Jurisdiction of 27.9.2012, ICSID Case No. ARB/06/2, at para. 266; Ambiente Ufficio S.p.A. and others v. Argentine Republic, Decision on Jurisdiction and Admissibility of 8.2.2013, ICSID Case No. ARB/08/9, at para. 517.

105 See: Z. Douglas, The Plea of Illegality in Investment Treaty Arbitration, 'ICSID Review - Foreign Investment Law Journal' Winter 2014, vol. 29, no 1, at pp. 155-186.

${ }^{106}$ Fraport AG Frankfurt Airport Services Worldwide v. Republic of the Philippines, Award of 16.8.2007, ICSID Case No. ARB/03/25, at para. 345. 


\section{Can human rights violations be successfully raised in investment arbitration?}

Following the review of the arbitral decisions, one needs to consider whether the principle of clean hands in the form of a plea of illegality may also cover breaches of human rights and could effectively be invoked by a respondent State. Until now, there has been no case in which an arbitral tribunal discussed the alleged abuses of human rights by a foreign investor. So far, the arbitral tribunals have discussed other types of illegal conduct on the part of an investor, such as misrepresentations made by the claimant, fraud, or bribery/corruption. However, bearing all of the above in mind, it should be considered whether violations of human rights by investors may be raised before an arbitral tribunal in order to contest the jurisdiction of a tribunal, admissibility, or substance of investment claims and thus deny the investor the substantive protection to which it is otherwise entitled. According to P. Dumberry and G. Dumas-Aubin, an arbitral tribunal should at least take into account human rights violations committed by the investor, provided that the BIT contains a broadly-worded dispute resolution clause and that violations are related to the investor's investment at the heart of the proceedings. ${ }^{107}$ Thus, such a tribunal could invoke the principle of clean hands under the general principle that investments must be made and subsequently performed in accordance with the law and hold that unacceptable conduct of the investor, consisting of a breach of human rights, must be regarded as an insurmountable obstacle to the admissibility of the investor's claims based on an investment treaty or deny the claims on the merits. Also, in the merits phase, an obligation to make reparations may be lifted or mitigated, according to Articles 31 and 39 of the ARSIWA. Obviously, not all breaches of human rights should exclude investors from the treaty protection, but only those that amount to a serious violation of human rights and are directly related to the investment. Thus, incidental or minor violations of human rights should not preclude the jurisdiction of

107 P. Dumberry, G. Dumas-Aubin, op. cit., at p. 372. See also: F. Balcerzak, Jurisdiction of Tribunals in Investor-State Arbitration and the Issue of Human Rights, 'ICSID Review Foreign Investment Law Journal' Winter 2014, vol. 29, no 1, at pp. 216, 228; R. Dolzer, Ch. Schreuer, Principles of International Investment Law, Oxford University Press, Oxford 2008, p. 273; I. Knoll-Tudor, The Fair and Equitable Treatment Standard and Human Rights Norm, [in:] P.M. Dupuy, F. Franconi, E.U. Petersmann (ed.), 'Human Rights in International Investment Law and Arbitration,' Oxford University Press, Oxford 2009, at pp. 310-343. 
a tribunal or admissibility of a claim and should eventually be considered in the merits phase, while assessing the alleged breaches of investment standards by the host State.

The principle of clean hands in the form of a plea of illegality, under which a tribunal may analyse the conduct of an investor abusing human rights, still does not sanction the view that the investor has direct obligations to respect human rights. Neither international investment law nor any international agreement impose any human rights obligation on investors. Soft law instruments adopted under the aegis of the UN and other international organisations have proved to be ineffective and insufficient means for the protection of human rights from violations committed by foreign investment corporations. However, nothing prevents host States from adopting such legislation that would impose the obligation to respect internationally recognised human rights upon investors. Thus, investors would be explicitly obliged to act in accordance with human rights or risk lack of investment protection under a BIT and, in the event it alleges, for example, the breach of the fair and equitable treatment standard, its case could be dismissed either in the jurisdiction/admissibility or the merits phase. Thus, investors have a direct obligation to act in accordance with the law and an indirect obligation to respect human rights, but only to such an extent as these rights are reflected in the domestic law of a host State. The respondent State could raise an objection consisting of a violation of human rights under the general principle of international investment law which denies the legal protection to investments made contrary to the law, and a tribunal would have jurisdiction over such human rights allegations to the extent that they are related or connected to the investor's investment in relation to which it filed a claim. ${ }^{108}$ Such an approach would also reflect the current trend prevailing in the international community to impose upon individuals direct human rights obligations and to establish mechanisms to adjudicate international responsibility of non-state actors, as well as to reinforce and follow the Norms on the Responsibility of Transnational Corporations and Other Business Enterprises with Regard to Human Rights and the Guiding Principles on Business and Human Rights.

108 P. Dumberry, G. Dumas-Aubin, op. cit., at pp. 361-362, who quote J. M. Dupuy, Unification Rather than Fragmentation of International Law? The Case of International Investment Law and Human Rights Law, [in:] P.M. Dupuy, F. Franconi, E.U. Petersmann (ed.), 'Human Rights in International Investment Law and Arbitration,' Oxford University Press, Oxford 2009, at pp. 61-62. 
The prohibition from breaching human rights may exist as a general principle of international investment law, as in Hamester, or, more likely, within the general principle that investments must be made, and subsequently performed, in accordance with the law. It should be assumed that the principle covers both the legality at the initiation of an investment and the legality during its subsequent performance. Requiring an investment to be made in accordance with the law of the host State in order to receive the protection under a BIT precludes claims made by investors abusing internationally recognised human rights. As the Inceysa Tribunal stated, the principle requiring making investments in accordance with the law may be inferred from the will of parties to a BIT. It may be even argued that it is difficult to assume that parties to a BIT would grant the treaty protection to investments which were made contrary to their own laws. Moreover, allowing investors to benefit from their illegal conduct would encourage them to act illegally and would not frustrate their interests in the future, in the event of a dispute with a host State. Such investment protection under a BIT would be based on unreasonable grounds and, therefore, investment tribunals should decline to adjudicate such cases and support the respect for the law. ${ }^{109}$

In conclusion, it is a principle international investment law that the investment must be lawful under the law of the host State. Therefore, in cases in which the investor has abused human rights, its claims should be reviewed and, if necessary, rejected due to lack of jurisdiction, rendered inadmissible, or dismissed in the merits phase under the said general principle. Thus, violations of human rights by investors would result in lack of legal protection under investment treaties. International investment law should not exist in isolation from general international law, including human rights, nor should it protect investments made or performed in breach of human rights. Therefore, at least to a limited extent, violations of human rights could be taken under consideration by arbitral tribunals.

109 See: Inceysa Vallisoletana, S.L. v. Republic of El Salvador, Award of 2.8.2006, ICSID Case No. ARB/03/26, at para. 244. "No legal system based on rational grounds allows the party that committed a chain of clearly illegal acts to benefit from them." 


\section{Bibliography}

A. Adeyeye, Corporate Responsibility in International Law: Which Way to Go? 'Singapore Yearbook of International Law' 2007, vol. 11.

F. Balcerzak, Jurisdiction of Tribunals in Investor-State Arbitration and the Issue of Human Rights, 'ICSID Review - Foreign Investment Law Journal' Winter 2014, vol. 29, no 1.

B. Bollecker-Stern, La préjudice dans la théorie de la responsabilité internationale, Paris 1973.

E. Borchard, Diplomatic Protection of Citizens Abroad, The Banks Law Publishing Co., New York 1915.

I. Brownlie, 2713. Meeting of the ILC, 1.5.2002, YILC 2002, vol. I.

C. Chiomenti, Corporations and the International Criminal Court, [in:] O. De Schutter (ed.), 'Transnational Corporations and Human Rights', Hart Publishing, Oxford, Portland 2006.

A. Clapham, The Question of Jurisdiction under International Criminal Law over Legal Persons, The Hague 2000.

J. Crawford, Second Report on State Responsibility, A.CN.4/498/Add.2.

R. Dolzer, Ch. Schreuer, Principles of International Investment Law, Oxford University Press, Oxford 2008.

Z. Douglas, The Plea of Illegality in Investment Treaty Arbitration, 'ICSID Review Foreign Investment Law Journal' Winter 2014, vol. 29, no 1.

P. Dumberry, G. Dumas-Aubin, When and How Allegations of Human Rights Violations can be Raised in Investor-State Arbitration, 'The Journal of World Investment \& Trade' 2012, vol. 13.

P. Dumberry, G. Dumas-Aubin, The Doctrine of "Clean Hands" and the Inadmissibility of Claims by Investors Breaching International Human Rights Law, 'Transnational Dispute Management' 2013, vol. 10, no 1.

J. M. Dupuy, Unification Rather than Fragmentation of International Law? The Case of International Investment Law and Human Rights Law, [in:] P.M. Dupuy, F. Franconi, E.U. Petersmann (ed.), 'Human Rights in International Investment Law and Arbitration,' Oxford University Press, Oxford 2009.

G. Fitzmaurice, The General Principles of International Law, RCADI 1957-II, vol. 92.

G. Hafner, 2590. Meeting of the ILC, 18.6.1999, YILC 1999, vol. I.

A. de Jonge, Transnational Corporations and International Law, Accountability in the Global Business Environment, Edward Elgar, Cheltenham 2011.

J. Kimerling, Environmental Adult of Texaco's Amazon Oil Fields: Environmental Justice or Business as Usual, The Recent Developments, 'Harvard Human Rights Journal' 1994, vol. 7.

I. Knoll-Tudor, The Fair and Equitable Treatment Standard and Human Rights Norm, [in:] P.M. Dupuy, F. Franconi, E.U. Petersmann (ed.), 'Human Rights in International Investment Law and Arbitration,' Oxford University Press, Oxford 2009. 
J. Larik, Corporate International Criminal Responsibility: Oxymoron or an Effective Tool for $21^{\text {st }}$ Century Governance?, [in:] (eds.) J. Hertwig, S. Maus, A. Meyer zu Schwabedissen \& M. Schuler, 'Global Risks - Constructing World Order through Law, Politics, and Economics', Peter Lang, Frankfurt am Main 2010.

R. Moloo, A Comment on the Clean Hands Doctrine in International Law, 'Transnational Dispute Management' 2011, vol. 8, no 1.

P. Muchlinski, Human Rights, Social Responsibility, and the Regulation of International Business: The Development of International Standards by Intergovernmental Organisations, 'Non-State Actors \& International Law' 2003, vol. 3, no 1.

S. Picciotto, Rights, Responsibilities, and Regulation of International Business, 'Columbia Journal of Transnational Law' 2003-2004, vol. 42.

S.R. Ratner; Corporations and Human Rights: A Theory of Legal Responsibility; 'Yale Law Journal' 2001-2002, vol. 111.

Ch. Rosseau, Droit international public. Tome V. Les rapports conflictuels, Paris 1983.

J.J.A. Salmon, Des « mains propres » comme condition de recevabilité des reclamations internationals, 'Annuaire Français de Droit International' 1964, vol. 10.

M.S. Sebastián, J.A. Córdoba, Yana Curi Report: The Impact of Oil Development on the Health of the People of the Ecuadorian Amazon, 1999.

P. Simons, Corporate Voluntarism and Human Rights: The Adequacy and Effectiveness of Voluntary Self-Regulation Regimes, 'Industrial Relations' 2004, vol. 59, no 1.

A. Teitelbaum, Observations on the Final Report of the Special Representative of the UN Secretary General on the issue of human rights and transnational corporations and other business enterprises, John Ruggie, 'TLWNSI Issue Brief' May 2011.

C.M. Vázquez, Direct vs. Indirect Obligations of Corporations Under International Law, 'Columbia Journal of Transnational Law' 2005, vol. 43.

D. Weissbrodt and M. Kruger, Norms on the Responsibilities of Transnational Corporations and Other Business Enterprises with Regard to Human Rights, 'American Journal of International Law' 2003, vol. 97.

D. Weissbrodt, Keynote Address: International Standard-Setting on the Human Rights Responsibilities of Business, 'Berkeley Journal of International Law' 2008, vol. 26. 